\title{
Stability increase in the activity of tolaasin inhibitors under reducing conditions
}

\author{
Yeong-Bae Yun ${ }^{1}$ (D) $\cdot$ Min-Hee $\mathrm{Kim}^{1}$ (D) $\cdot$ Young-Kee Kim ${ }^{1}$
}

\section{환원 조건에서 톨라신 저해 물질 활성의 안정성 증가}

\author{
윤영배 $^{1} \cdot$ 김민희 $^{1} \cdot$ 김영긴 $^{1}$
}

Received: 18 September 2017 / Accepted: 28 September 2017 / Published Online: 31 December 2017

(C) The Korean Society for Applied Biological Chemistry 2017

\begin{abstract}
Tolaasin, peptide toxin produced by Pseudomonas tolaasii, causes a brown blotch disease on the cultivated mushrooms. Tolaasin peptides form membrane pores and disrupt cellular membrane structure. Molecular actions of tolaasin consist of the aggregation of peptide molecules, binding to the cell membrane, and formation of membrane pores. Therefore, the inhibitions of any of these actions are able to suppress the blotch disease. We have isolated and identified several tolaasin inhibitors (named tolaasin inhibitory factors, TIF) from food additives. TIFs were able to suppress the blotch-formation by the pathogen inoculated to the mushrooms. In this study, TIFs were incubated under various conditions and their activities for the inhibition of tolaasininduced hemolytic activity were investigated. Since TIFs are unsaturated carbon compounds, they were sensitive to the air exposure and light irradiation. In the anaerobic conditions, TIFs were stable and their activities were decreased by $10 \%$ for three months. However, near $90 \%$ of TIF activity was suppressed by two weeks in the presence of air and sun light. Temperature did not show any significant effects on the activity of TIF, since storages at $5,25,45{ }^{\circ} \mathrm{C}$ did not show any difference. Therefore, for the stable storage of TIF compounds, container should be designed to be dark and air-tight.
\end{abstract}

Young-Kee $\operatorname{Kim}(\triangle)$

E-mail: ykkim10@cbnu.ac.kr

${ }^{1}$ Department of Environmental and Biological Chemistry, Chungbuk National University, Cheongju, Chungbuk 28644, Republic of Korea

This is an Open Access article distributed under the terms of the Creative Commons Attribution Non-Commercial License (http://creativecommons. org/licenses/by-nc/3.0/) which permits unrestricted non-commercial use, distribution, and reproduction in any medium, provided the original work is properly cited.
Keywords Cytotoxicity of tolaasin . Peptide toxin - Pore formation $\cdot$ Pseudomonas tolaasii $\cdot$ Storage conditions

\section{서 론}

갈반병(Brown blotch disease)은 인공재배 버섯의 주된 세균병 으로 주로 자실체 형성 초기에 원인 균주인 Pseudomonas tolaasii의 감염으로 발생하며, 이 균이 생성하는 펩티드 독소인 톨라신의 작용에 의해 버섯 조직이 파괴됨으로써 발병한다(Peng 1986). P. tolaasii는 다습한 환경에서 지하수나 대기를 통해 버 섯조직 및 균사에 감염될 수 있으며, 특히 버섯의 저항성이 약 할 때 병원균은 빠르게 증식하여 톨라신을 분비한다(Hutchison 과 Johnstone 1993). 갈반병은 균사 및 자실체 전체의 성장을 중지시키며 진한 갈색으로 변화시키거나(Fletcher와 Gaze 2008), 버섯의 갓조직에 갈색 반점을 형성하여 상품성을 없애버리는 등 버섯을 재배하는 농가에 치명적인 경제적 손실을 일으킨다 (Munsch와 Alatossava 2002). 또한 발생한 갈반병은 빠른 확산 속도로 주변의 재배농가나 지역 전체로 번질 수 있다. 갈반병 의 방제를 위하여 sodium hypochlorite 등으로 병원균의 성장을 억제하거나(Oh 등, 2000), 생물학적인 방제 방안으로 길항균 (Tajalipour 등, 2014)과 박테리오파지(Kim 등, 2011) 등을 실험 적으로 시도하였다. 그러나, 길항균은 큰 성과를 보여주지 못하 였으며, 박테리오파지를 이용한 병원균의 방제는 긍정적인 효과 가 얻어졌으나, 파지저항성 병원균의 발생으로 저항성 균주의 특성 연구가 선행되어야 기대효과를 얻을 수 있다(Park 등, 2016).

톨라신은 짧은 지방산과 18 개의 아미노산으로 이루어져 있고, 분자 내에 친수성과 소수성 부위를 동시에 갖는 양친매성 펩티 드 독소이다. 톨라신에 의한 갈반병의 발생은 버섯 세포막으로 
유입된 톨라신 분자들의 다중화결합으로 인한 pore 형성, pore 를 통한 물질의 이동 및 이에 따른 세포내 삼투압 교란으로 세 포 및 버섯 조직이 파괴되어 나타난다(Brodey 등, 1991). 톨라 신의 작용기작은 벌독의 주요 독성 성분인 melittin (Raghuraman 과 Chattopadhyay 2007; van den Bogaart 등, 2008; Lee 등, 2013)과 Pseudomonas corrugata에 의해 생성되어 토마토의 괴 사를 일으키는 corpeptin (Emanuele 등, 1998) 등의 다른 poreforming 독소와 유사하다.

식품첨가물로부터 톨라신의 세포독성을 억제하는 물질을 얻 었으며, 이들을 Tolaasin inhibitory factors (TIF)라 명명하고, 용혈 활성 및 버섯조직함몰검정법(pitting test), 느타리버섯의 균 상재배실험에서 톨라신의 독성 작용에 대한 이들의 억제 효과 를 확인하였다(Yun 등, 2017). 본 연구는 갈반병 발생을 억제하 는 효과가 뛰어난 $\mathrm{TIF}$ 의 보관 중 안정성을 높이는 방안의 연 구로 수행되었다. 버섯 재배환경에서의 실용화를 위하여 톨라신 의 독성 작용을 가장 효과적으로 억제하는 $\mathrm{TIF}$ 를 선발한 후, 다양한 조건에서 $\mathrm{TIF}$ 의 안정성을 확인하였고, 일반적인 항산화 제로 많이 사용되는 Ascorbic acid와 Dithiothreitol을 첨가하였 을 때, 항산화제에 의한 TIF의 안정성과 톨라신의 용혈활성에 미치는 영향을 조사하였다.

\section{재료 및 방법}

\section{톨라신의 순수분리}

$25{ }^{\circ} \mathrm{C}$ 의 Pseudomonas agar $\mathrm{F}$ (Bacto-tryptone $10 \mathrm{~g}$, Bacto-peptone $10 \mathrm{~g}, \mathrm{MgSO}_{4} 1.5 \mathrm{~g}, \mathrm{~K}_{2} \mathrm{HPO}_{4} 1.5 \mathrm{~g}$, Glycerol $10 \mathrm{~mL}$, Agar $15 \mathrm{~g} / 1 \mathrm{~L}$ 증류수) 액체 배지에 P. tolaasii 균주를 접종한 후, 정 체기에 도달하도록 18 시간 이상 진탕배양하였다. 배양액을 Type 16 rotor (Beckman Instruments, Inc., Palo Alto, CA, USA) 를 이용하여 $8,000 \mathrm{rpm}$ 에서 30 분간 원심분리하여 균체를 제거 한 배양상징액을 얻었다(Cho 등, 2000). 톨라신을 포함한 배양 상징액을 용혈활성 측정에 사용하였으며, 필요에 따라 톨라신 분자를 순수분리하여 특성을 조사하였다. 순수분리과정은 간략 히 배양상징액에 ammonium sulfate를 처리한 후 초고속원심분 리기를 이용하여 톨라신의 침전을 얻었다. 침전을 용해하여 Gel permeation chromatography과정으로 순수분리하여 분액을 만들 어 초저온냉동고 $\left(-70{ }^{\circ} \mathrm{C}\right)$ 에 보관하며 사용하였다.

\section{톨라신에 의한 용혈활성 측정}

톨라신의 용혈활성 측정은 Cho 등(2000)의 방법에 따라 쥐의 적혈구를 이용하여 수행하였다. 용혈활성을 측정하는데 사용한 적혈구는 사용하기 바로 직전에 $\mathrm{HBS}$ 완충액으로 10 배 희석한 후 최종반응용액에 $10 \%$ 가 되도록 처리하였다. 톨라신을 $1 \mathrm{HU}$ 처리하여 30 분간 배양하면서 $\mathrm{UV} / \mathrm{Vis}$ 분광광도계를 이용하여 $600 \mathrm{~nm}$ 에서 흡광도 감소를 측정하여 적혈구 세포의 파괴 활성 을 평가하였다.

\section{TIF의 효과 및 안정성 측정}

TIF는 Sakamoto Yakuhin Kogyo (Osaka, Japan)와 MitsubishiKagaku Foods Corporation (Tokyo, Japan)의 제품을 남영상사 를 통해 공급받았다. TIF 10 과 TIF 16 은 polyglycerol fatty acid ester이며, TIF 12는 sucrose fatty acid ester 화합물이다 (Yun 등, 2017). TIF의 활성 변화는 각 $\mathrm{TIF}$ 를 $\mathrm{HBS}$ 완충액 $(\mathrm{pH}$ 7.4)에 희석한 후, 적혈구와 톨라신을 포함하는 최종 반응용액 의 $10 \%$ 가 되도록 처리하여 톨라신의 활성 저해를 측정하였다. 실험 시작일을 기준일로 하여 ' 0 day'로 설정하였으며, 각 TIF 가 공통적으로 톨라신 억제 효과를 보인 $10 \mu \mathrm{M}$ 의 농도에서 $\mathrm{TIF}$ 의 경시적 활성 변화를 측정하였다. TIF의 안정성 증대를 위해 $\mathrm{TIF}$ 용액에 항산화제인 Ascorbic acid $0.1 \mathrm{mM}$, Dithiothreitol $0.1 \mathrm{mM}$ 의 농도로 첨가한 후, 2주간 상온에 보관하며 2일마다 $\mathrm{TIF}$ 의 활성 변화를 측정하였다.

\section{결과 및 고찰}

\section{보관조건에 따른 TIF 안정성}

일반적으로 불포화 탄화수소 화합물은 분자 내에 탄소-탄소 이 중결합을 포함하고 있어 산소와의 반응성이 높으며 $(\mathrm{Li} \mathrm{2010),}$ 불포화 지방산 화합물인 TIF도 공기와의 접촉으로 산화반응이 쉽게 일어날 것으로 예측된다. 따라서 $\mathrm{TIF}$ 의 톨라신 억제활성 유지를 위한 최적 보관 조건을 조사하기 위하여 다양한 환경에 서 시간 경과에 따른 $\mathrm{TIF}$ 의 활성 변화를 측정하였다. 빛에 의 한 영향은 은박지로 감싼 후 암실에서 보관하여 빛을 차단하였 으며, 혐기적 조건은 질소 가스로 충전한 상태로 유지하였으며, 시료채취 후에는 매번 질소 가스를 주입하여 보관하였다. 산소 를 제거한 상태의 상온에서 $\mathrm{TIF}$ 의 활성은 보관 초기에 비하여 $80 \%$ 이상 활성이 유지되었다(Fig. 1(A)). 반면, TIF 용액을 공 기에 노출시킨 조건에서는 14 일이 경과하였을 때 TIF 10 과 TIF 12 는 $90 \%$ 이상, TIF 16 은 약 $80 \%$ 이상의 활성 감소를 보였다 (Fig. 1(B)). 이러한 결과는 TIF의 톨라신 억제 활성이 산소 접 촉에 의해 급격히 감소함을 보여준다. 따라서 $\mathrm{TIF}$ 의 안정성을 높이기 위해서는 TIF 성분을 함유한 용액의 산소 접촉을 차단 해야 할 것이다.

$\mathrm{TIF}$ 활성을 최적의 상태로 유지할 수 있는 보관온도를 조사 하기 위하여 TIF 10 과 TIF 12 , TIF 16 을 각각 $5,25,45{ }^{\circ} \mathrm{C}$ 에서 보관하며 TIF의 활성을 측정하였다(Fig. 2). 이 실험은 각 온도에서 공기와 접촉한 상태로 수행하여 10 일 후에 $\mathrm{TIF}$ 의 활 성감소를 측정하였다. TIF 10 과 TIF 16 은 온도와 무관하게 일 정한 활성 감소를 보여, $\mathrm{TIF} 10$ 은 $25-35 \%$ 의 활성을 보였고, $\mathrm{TIF} 16$ 은 $30-50 \%$ 의 활성을 보였다. 이처럼 $\mathrm{TIF} 10$ 과 $\mathrm{TIF} 16$ 은 공기와 접촉한 상태에서 보관 온도에 따른 활성의 차이가 크지 않았다. TIF 12 의 경우에는 5 와 $25{ }^{\circ} \mathrm{C}$ 에서 활성이 $15-$ $20 \%$ 로 감소하였으나, $45{ }^{\circ} \mathrm{C}$ 에서 보관하였을 때는 활성이 비정 상적 수치를 보여 자료를 보이지 않았다.

빛의 조사 유무에 따른 $\mathrm{TIF}$ 활성의 경시적 변화를 측정하기 위하여, $10 \mu \mathrm{M}$ 의 동일한 농도로 제조한 $\mathrm{TIF} 10$, TIF $12, \mathrm{TIF}$ 16 을 각각 은박지로 햇빛을 차단한 대조구(filled symbol)와 햇 빛에 노출시킨 실험구(open symbol)를 준비하여, 상온에서 공기 와 접촉하며 14 일간 $\mathrm{TIF}$ 의 활성변화를 측정하였다(Fig. 3). 각 $\mathrm{TIF}$ 를 함유한 용액의 유리용기를 남향의 창가에 14 일간 보관하 며 3일마다 시료를 채취하여 TIF의 활성을 측정하였다. 대조구 는 각 $\mathrm{TIF}$ 용액을 은박지로 감싸 빛을 차단하였으며, 빛 조사 의 유무에 따라 TIF 활성 변화에서 $\mathrm{TIF}$ 종류별로 서로 다른 차 

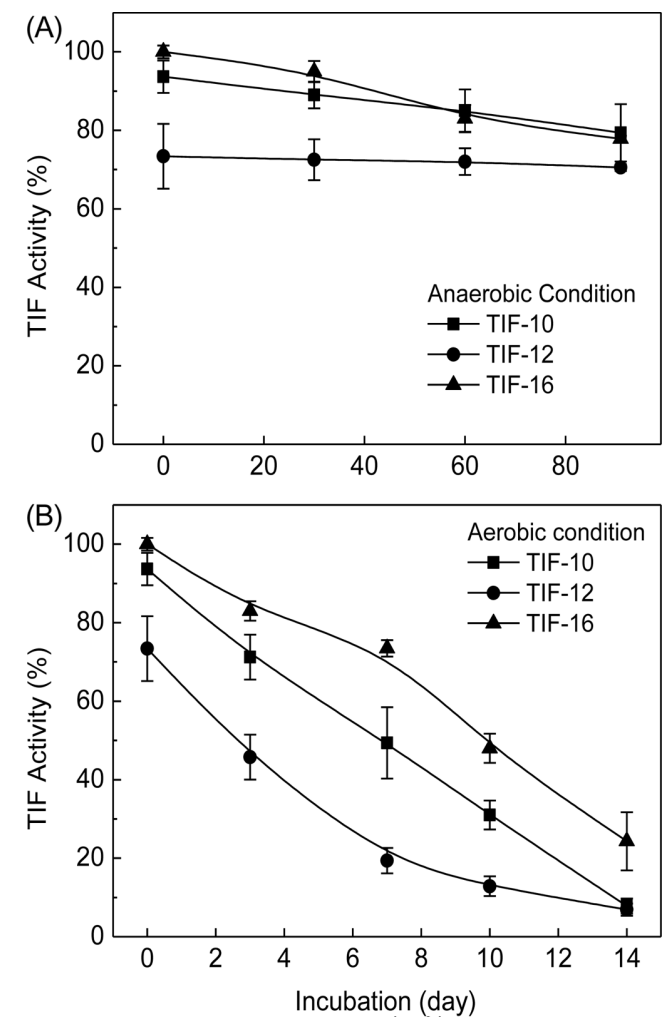

Fig. 1 Effects of various storage conditions on the activity of TIF. The inhibitory effects of TIFs on tolaasin-induced hemolysis were measured in anaerobic (A) and aerobic (B) conditions

이를 나타냈다. 특히, TIF 10 은 빛을 차단한 경우 시간 경과에 따라 일정한 감소 경향을 보이는 반면, 빛을 조사한 경우에는 급격하게 감소하여 7 일차에 활성이 $90 \%$ 이상 감소하였다. TIF 16 은 경시적 변화에서 약간의 차이를 보였으나, 14 일차에는 대 조구와 같은 정도로 감소하였으며, TIF 12 는 빛의 유무에 따른 $\mathrm{TIF}$ 의 활성 변화에 차이가 없었다. 즉 $\mathrm{TIF}$ 의 활성은 화합물의 구조에 따라 서로 다른 감소 경향을 보였으며, 빛이 차단된 조 건에서보다 빛에 노출된 조건에서 $\mathrm{TIF}$ 의 톨라신 억제활성이 급 격하게 감소함을 알 수 있었다.

\section{TIF의 효과 유지를 위한 항산화제 첨가}

여러 조건에서 $\mathrm{TIF}$ 의 톨라신 억제활성을 경시적으로 확인한 결 과, 산화, 빛, 온도에 따라 TIF 활성이 변화하는 것을 알 수 있 다. 특히 공기와 접촉하지 않은 혐기적 조건에서 $\mathrm{TIF}$ 는 90 일이 상 안정하였으며 톨라신의 용혈활성을 효과적으로 억제하였다 (Fig. 1(A)). 반면, 공기와 접촉한 호기적 조건에서는 14 일 경과 시 $\mathrm{TIF}$ 의 톨라신 억제활성이 $80 \%$ 이상 감소하였다(Fig. 1(B)). 이처럼 TIF의 안정성에 가장 큰 영향을 끼치는 요인은 공기 중 산소와의 접촉 유무로 나타났다. 따라서 일반적인 항산화제로 알려진 Ascorbic acid (Dolatabadian과 Jouneghani 2009)와 Dithiothreitol (DTT) (Clement 등, 2005)을 TIF 용액에 첨가하 고 이들에 의한 TIF의 톨라신 억제활성 변화를 조사하였다.

공기와 접촉한 조건에서 항산화제 첨가는 $\mathrm{TIF}$ 의 안정성을 크 게 증가시켰다(Fig. 4). 항산화제를 첨가하지 않은 경우에는 톨

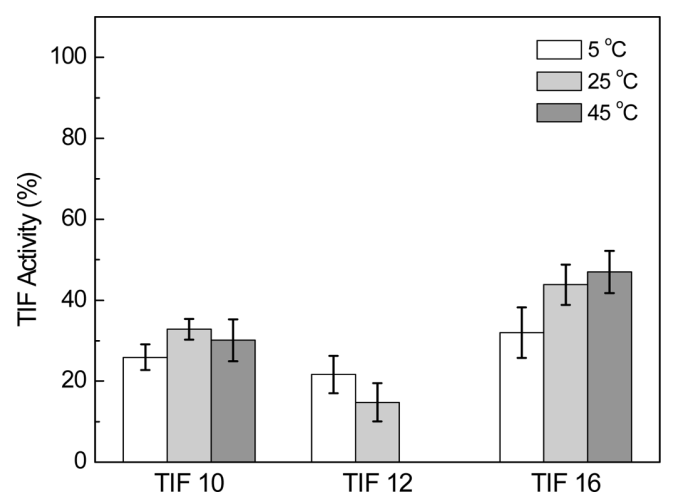

Fig. 2 Effect of storage temperature on the activity of TIF. TIFs were stored for 10 days at the indicated temperatures in aerobic condition. The activity of TIF 12 at $45{ }^{\circ} \mathrm{C}$ was not applicable

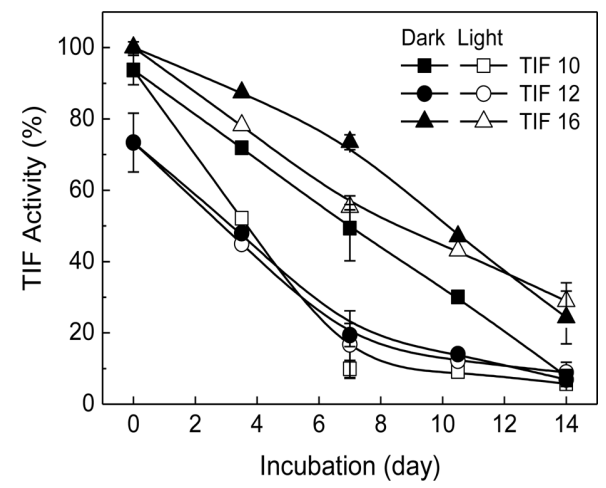

Fig. 3 Effect of sun light on the activity of TIF in the condition of air contact. TIF solutions were stored either in dark (filled symbols) or under light without cover (open symbols)

라신의 세포독성을 억제하는 $\mathrm{TIF}$ 의 활성이 현저히 감소하였으 나, 항산화제를 첨가한 경우에는 $\mathrm{TIF}$ 활성이 처음 상태와 같게 유지되거나 활성의 감소가 적어졌다. Ascorbic acid를 첨가한 경 우 10 일 후에는 TIF 10 과 TIF 16 의 활성이 $90 \%$ 이상 유지되 었으나, DTT를 첨가한 경우에는 활성이 $60-90 \%$ 의 활성을 보 였다. 이 결과는 ascorbic acid가 DTT보다 TIF의 안정성에 더 큰 효과가 있음을 보여준다.

동일한 조건에서 $\mathrm{TIF}$ 용액의 공기 접촉을 차단하였을 경우, 항산화제의 효과는 더욱 증가하였다(Fig. 5). 밀폐된(air-tight) 조 건에서는 항산화제를 첨가하지 않은 경우에도 $\mathrm{TIF}$ 의 활성이 지 속되었다. 처리 10 일째 TIF 10 의 경우 모든 처리구에서 $95 \%$ 이상의 활성이 유지되었다. 그러나 TIF 16 에서는 항산화제 처 리구에 따라 활성이 $80-85 \%$ 를 유지하였다.

질소를 충전하여 $\mathrm{TIF}$ 활성의 변화를 측정한 결과에서는(Fig. 6), TIF 10 의 경우 $90 \%$ 이상의 활성을 보여 밀폐 조건과 유사 하였다. 그러나 TIF 16 의 처리구에서는 대조구의 경우 활성이 $60 \%$ 로 약간 감소하였고, ascorbic acid처리구에서는 밀폐조건과 같은 $90 \%$ 의 활성을 보였다. 반면 DTT를 처리한 질소충전 조 건의 TIF 16 에서는 급격한 활성감소를 보였으나 자세한 기작은 알 수 없었다.

TIF 10 은 모든 조건의 ascorbic acid와 DTT 처리구에서 


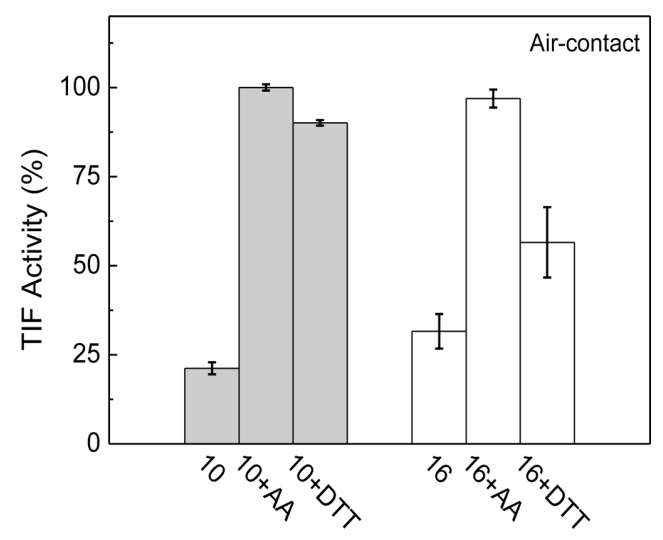

Fig. 4 Effects of antioxidants on the activities of TIF 10 and TIF 16. TIF solutions were stored in air-contact condition for 10 days. Antioxidants, ascorbic acid (AA) and dithiothreitol (DTT), were added. 10; TIF 10, 16; TIF 16

$90 \%$ 이상의 높은 활성을 유지하였다. 반면 TIF 16 의 경우는 ascorbic acid 처리구에서 $85-90 \%$ 의 활성을 보였으나, DTT 처 리구에서는 환경조건에 따라 활성이 크게 변화하였다. 공기와 접촉한 조건에서 DTT를 첨가하여도 $\mathrm{TIF} 16$ 의 활성은 $60 \%$ 이 하로 감소하였고, 질소충전 조건에서는 $10 \%$ 이하로 감소하였다. $\mathrm{TIF} 16$ 의 DDT 처리구에 질소 충전시 급격한 활성감소의 원인 은 알 수 없으나, 질소 포화용액에서 DTT 처리에 따른 TIF 16 의 용해도 감소 등 다양한 원인이 조사되어야 할 것이다.

버섯재배에 영향을 끼치는 환경적 인자는 온도 및 습도 등 다양하지만(Uddin 등, 2011), 이중 적절한 습도를 유지하는 것 은 매우 중요하며, 농가에서는 수시로 살수하여 버섯 표면에 적 정 습도를 유지한다. 따라서 TIF를 이용한 갈반병의 방제를 위 해서는 필요에 따라 TIF를 살수용수에 일정농도로 첨가한 후 살수과정을 통하여 버섯 표면에 적용하는 방안이 적절할 것으 로 판단된다. TIF를 처리하면 P. tolaasii가 일부 감염되어 증식 하며 톨라신을 분비하더라도 버섯 표면에 잔류하는 TIF에 의해 병 발생이 억제될 것이다. TIF에 의해 톨라신의 작용이 억제되 면 P. tolaasii는 세포의 파괴를 통해 얻었던 양분을 얻지 못하 고 대량증식에 실패하여 갈반병을 유발하지 못할 것이다.

$\mathrm{TIF}$ 로 작용하는 화합물은 대부분 불포화 지방산 에스터로 구 성된 유기화합물이므로 빛, 산화, 온도 등 다양한 조건에 의해 $\mathrm{TIF}$ 활성이 영향을 받을 수 있다. 본 연구에서 $\mathrm{TIF}$ 의 활성은 빛과 공기의 접촉 하에 빠르게 감소하였으며, 특히 공기와의 산 화 반응에 의해 활성이 크게 감소함을 확인하였다. 불포화 지 방산으로 이루어진 TIF는 대기에 노출되어 산화됨으로써 시간 이 경과할수록 $\mathrm{TIF}$ 가 분해되어 활성이 감소하는 것으로 생각된 다. 이에 따라 공기가 차단된 혐기적 조건에서는 $\mathrm{TIF}$ 의 활성이 3 개월이상 지속되었지만 공기에 노출 시킨 경우 2 주 내에 활성 이 $1 / 5$ 수준으로 떨어졌다(Fig. 1).

산화뿐만 아니라 빛의 조사도 $\mathrm{TIF}$ 의 활성 감소를 촉진시켰는 데(Fig. 3), 이는 빛에 의한 불포화 지방산의 산화반응인 광산 화(photo-oxidation)로 설명할 수 있다. 산소는 2가지 형태로 존 재하는데, 이중 TIF의 불포화화합물에 대한 반응성은 들뜬 상 태인 singlet 산소분자 $\left({ }^{1} \mathrm{O}_{2}\right)$ 가 에너지가 낮은 triplet 분자 $\left({ }^{3} \mathrm{O}_{2}\right)$ 보 다 높다. 빛은 공기중 산소 ${ }^{3} \mathrm{O}_{2}$ 를 ${ }^{1} \mathrm{O}_{2}$ 로 활성화시키는데 필요

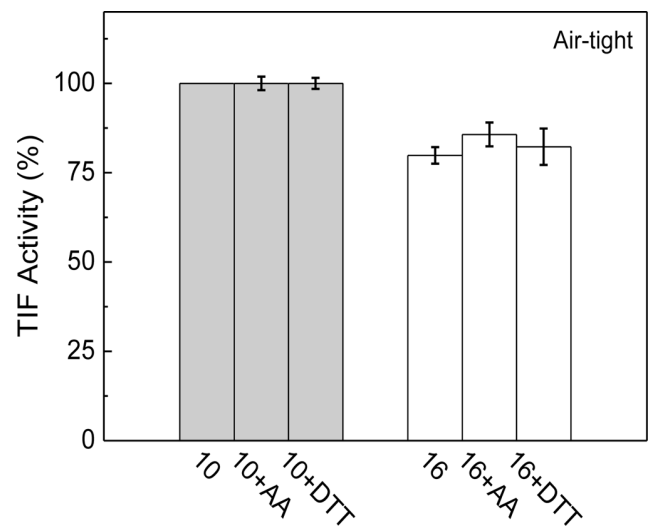

Fig. 5 Stability of TIF in air-tight condition. Antioxidants were added as indicated and incubated for 10 days

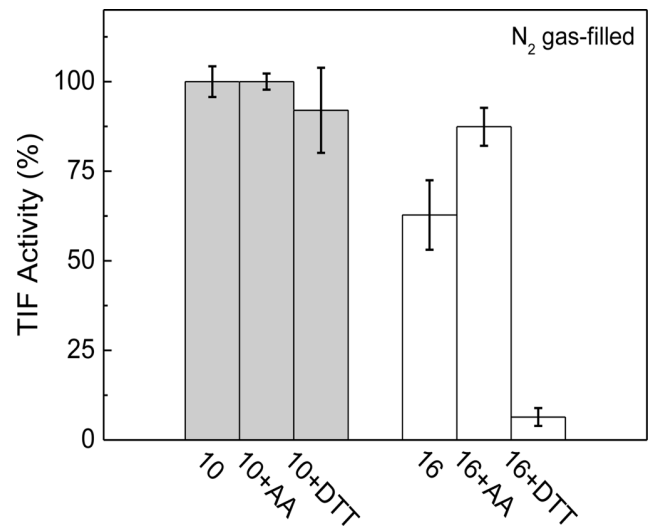

Fig. 6 Stability of TIF in the nitrogen gas-filled condition. Antioxidants were added as indicated and incubated for 10 days

한 에너지를 공급하며, 이렇게 생성된 친전자성의 ${ }^{1} \mathrm{O}_{2}$ 와 전자 가 풍부한 이중 결합 사이의 엔 반응(ene reaction)을 일으킨다. 광산화반응을 통해 생성된 1차 산화물은 allylic hydroperoxide 이며, 이 물질은 불안정하여 다양한 2차 산화물로 분해된다 (Gunstone 1984; Ahmad 2017). 이러한 과정을 통해 TIF는 빛 을 차단한 조건에서보다 빛에 노출된 조건에서 빠른 활성 감소 를 보였다.

항산화제 처리는 산화반응이 시작되는 것을 막을 수 있으며, 다른 분자에 의한 2차 산화도 억제할 수 있을 것이다(Chatterjee 등, 2007). 항산화제인 Ascorbic acid와 dithiothreitol을 TIF 용 액에 첨가하였을 경우, $\mathrm{TIF}$ 의 산화를 방지하여 TIF의 톨라신 억제활성이 지속적으로 유지되었다. 또한 항산화제의 첨가에 더 하여 TIF용액이 담긴 보관 용기 내부로 공기가 유입되는 것을 차단하였을 경우 $\mathrm{TIF}$ 의 활성은 더욱 효과적으로 지속되었다. 이 러한 결과로 미루어 볼 때, 산화, 빛, 온도 등 다양한 조건들 중에서 TIF 활성을 안정적으로 유지시키기 위한 가장 중요한 인자는 산화를 방지하는 것이며, 만일 TIF를 제품화하기 위해 서는 제조 및 유통과정 중 산화에 따른 $\mathrm{TIF}$ 의 활성 감소를 방 지하기 위하여 항산화제를 첨가하거나, TIF 제제가 산소와의 접 촉을 차단할 수 있는 용기의 개발이 함께 이루어져야 할 것이 다. 또한, 빛 조사에 따른 $\mathrm{TIF}$ 의 분해를 막아 $\mathrm{TIF}$ 안정성을 유 
지할 수 있도록 빛이 투과하지 않는 보관용기를 제작하여야 하 고, TIF 종류와 제제에 따라 용해 방법과 보관 및 사용온도를 적절히 설정한다면 $\mathrm{TIF}$ 를 이용한 갈반병 억제효과를 높일 수 있을 것이다.

\section{초 록}

톨라신은 Pseudomonas tolaasii에 의해 생성되는 펩티드 독소이 며, 인공재배 버섯에 갈반병을 일으킨다. 톨라신 펩티드는 막에 pore를 형성하고, 세포막 구조를 파괴한다. 톨라신의 분자 작용 은 톨라신 분자들의 응집, 세포막 결합, 세포막에서의 pore 형 성으로 이루어져 있다. 따라서, 이 작용의 억제는 갈반병을 억 제할 수 있다. 식품첨가물로부터 몇몇의 톨라신 저해제(tolaasin inhibitory factors, TIF)를 얻었다. TIF는 버섯에 감염된 병원균 에 의한 갈반 형성을 억제할 수 있었다. 본 연구에서는 TIF를 다양한 조건에서 보관하였으며, 톨라신에 의한 세포 독성의 저 해에 대해 이들의 활성을 조사하였다. TIF는 불포화탄소 화합 물이기 때문에 대기 노출과 빛 조사에 민감하다. 혐기적 조건 에서 $\mathrm{TIF}$ 는 3 개월동안 안정하였고, 효과는 $10 \%$ 정도 감소하였 다. 그러나 빛과 공기와 접촉한 조건에서는 2 주동안 $90 \%$ 가까 이 $\mathrm{TIF}$ 활성이 억제되었다. $5,25,45{ }^{\circ} \mathrm{C}$ 의 저장온도에서는 어 떠한 차이도 보이지 않았기 때문에 온도는 TIF의 안정성에 유 의적인 영향을 끼치지 않았다. 따라서, TIF 화합물의 안정적인 저장을 위해서는 용기는 밀폐되고, 빛은 차단되어야 한다.

Keywords 슈도모나스 톨라시 · 저장 조건 · 톨라신의 세포독성 · 펩티드 독소 · Pore 형성

감사의 글 이 논문은 2017 년도 정부(교육부)의 재원으로 한국연구재단의 지원을 받아 수행된 기초연구사업임(No. 2017R1D1A3B03032718).

\section{References}

Ahmad MU (2017) Fatty acids: chemistry, synthesis, and applications. Naturally occurring fatty acids: source, chemistry, and uses, 1st edn. Academic press and AOCS press, London, pp 24-71

Brodey CL, Rainey PB, Tester M, Johnstone K (1991) Bacterial blotch disease of the cultivated mushroom is caused by an ion channel forming lipodepsipeptide toxin. Mol Plant Microbe Interact 4: 407-411

Chatterjee S, Zareena N, Gautam S, Soumyakanti A, Prasad SV, Arun S (2007) Antioxidant activity of some phenolic constituents from green pepper (Piper nigrum L.) and fresh nutmeg mace (Myristica fragrans). Food Chem 101: 515-523
Cho KH, Park KS, Kim YK (2000) Hemolytic properties of tolaasin causing the brown blotch disease on oyster mushroom. J Korean Soc Agric Chem Biotech 43: 190-195

Clement MV, Sivarajah S, Pervaiz S (2005) Production of intracellular superoxide mediates dithiothreitol-dependent inhibition of apoptotic cell death. Antioxid Redox Signal 7: 456-464

Dolatabadian A, Jouneghani RS (2009) Impact of exogenous ascorbic acid on antioxidant activity and some physiological traits of common bean subjected to salinity stress. Not Bot Hort Agrobot Cluj 37: 165-172

Emanuele MC, Scaloni A, Lavermicocca P, Jacobellis NS, Camoni L, Di Giorgio D, Pucci P, Paci M, Segre A, Ballio A (1998) Corpeptins, new bioactive lipodepsipeptides from cultures of Pseudomonas corrugata. FEBS Lett. 433: 317-320

Fletcher JT, Gaze TH (2008) Mushroom: Pest and Disease Control, 2nd edn. Manson Publishing, London, pp 192

Gunstone FD (1984) Reaction of oxygen and unsaturated fatty acids. J Am Oil Chem Soc 61: 441-447

Hutchison MI, Johnstone K (1993) Evidence for the involvement of the surface active properties of the extracellular toxin tolaasin in the manifestation of brown blotch disease symptoms by Pseudomonas tolaasii on Agaricus bisporus. Physiol Mol Plant Pathol 42: 273-384

Kim MH, Park SW, Kim YK (2011) Bacteriophages of Pseudomonas tolaasii for the biological control of brown blotch disease. J Korean Soc Appl Biol Chem 54: 99-104

Lee MT, Sun TL, Hung WC, Huang HW (2013) Process of inducing pores in membranes by melittin. Proc Natl Acad Sci USA 110: 14243-14248

Li H (2010) Kinetics and mechanisms of the oxidation processes for unsaturated hydrocarbon modified scavengers. Dissertation, University of Toledo

Munsch P, Alatossava T (2002) Several pseudomonads, associated with cultivated mushrooms Agaricus bisporus and Pleurotus sp., are hemolytic. Microbiol Res 157: 311-315

Oh SJ, Kim HK, Kim HK, Fermor TR (2000) Effect of sodium hypochlorite for controlling bacterial blotch on Pleurotus ostreatus. Mycobiol 28: $123-126$

Park SJ, Han JH, Kim YK (2016) Isolation of bacteriophage-resistant Pseudomonas tolaasii strains and their pathogenic characters. J Appl Biol Chem 59: 351-356

Peng JT (1986) Resistance to disease in Agaricus bisporus (lange) Imbach. Dissertation, Department of Plant Science, University of Leeds, UK

Raghuraman H, Chattopadhyay A (2007) Melittin: a membrane-active peptide with diverse functions. Biosci Rep 27: 189-223

Tajalipour S, Hassanzadeh N, Jolfaee HK, Heydari A, Ghasemi A (2014) Biological control of mushroom brown blotch disease using antagonistic bacteria. Biocontrol Sci Technol 24: 473-484

Uddin MN, Yesmin S, Khan MA, Tania M, Moonmoon M, Ahmed S (2011) Production of oyster mushrooms in different seasonal conditions of Bangladesh. J Sci Res 3: 161-167

van den Bogaart G, Guzman JV, Mika JT, Poolman B (2008) On the mechanism of pore formation by melittin. J Biol Chem 238: 3385433857

Yun YB, Kim MH, Han JH, Kim YK (2017) Suppression of brown blotch disease by tolaasin inhibitory factors. J Appl Biol Chem 60: 179-184 